\title{
University Reactor Conversion Lessons Learned Workshop for Texas A\&M University Nuclear Science Center
}

Eric C. Woolstenhulme Dana M. Meyer

April 2007

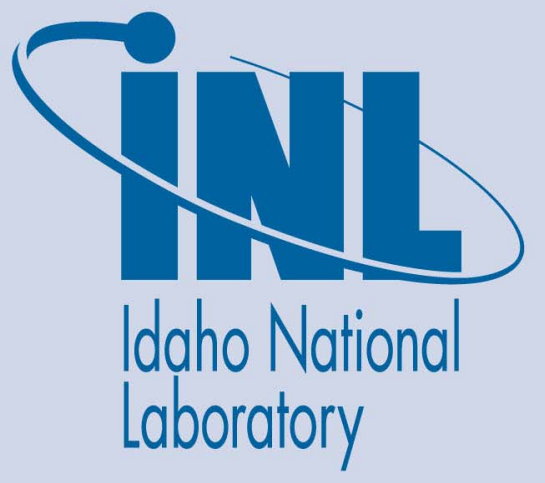

The INL is a U.S. Department of Energy National Laboratory operated by Battelle Energy Alliance 


\title{
University Reactor Conversion Lessons Learned Workshop for Texas A\&M University Nuclear Science Center
}

\author{
Eric C. Woolstenhulme
}

Dana M. Meyer

April 2007

\begin{abstract}
Idaho National Laboratory
Idaho Falls, Idaho 83415
\end{abstract}

Prepared for the

U.S. Department of Energy

Office of Nuclear Nonproliferation and Security Affairs

Under DOE Idaho Operations Office

Contract DE-AC07-05ID14517 


\begin{abstract}
The Department of Energy's Idaho National Laboratory, under its programmatic responsibility for managing the University Research Reactor Conversions, has completed the conversion of the reactor at the Texas A\&M University Nuclear Science Center Reactor. With this work completed and in anticipation of other impending conversion projects, INL convened and engaged the project participants in a structured discussion to capture the lessons learned. This lessons learned process has allowed us to capture gaps, opportunities, and good practices, drawing from the project team's experiences. These lessons will be used to raise the standard of excellence, effectiveness, and efficiency in all future conversion projects.
\end{abstract}




\section{CONTENTS}

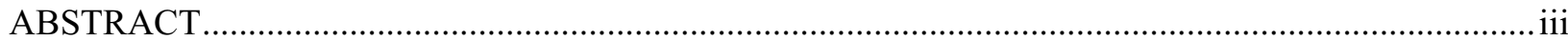

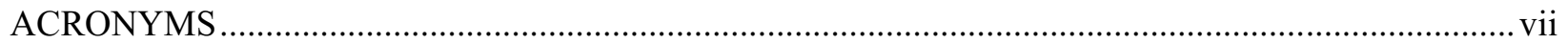

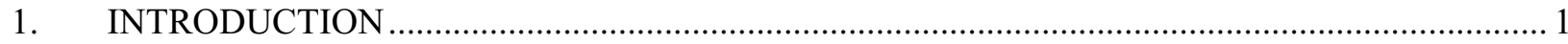

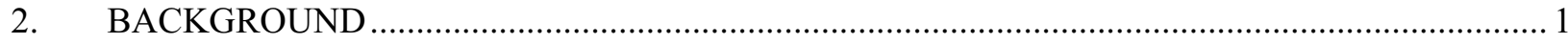

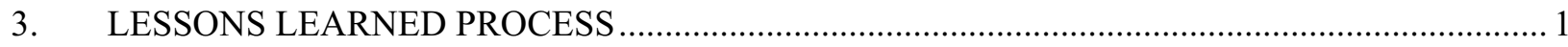

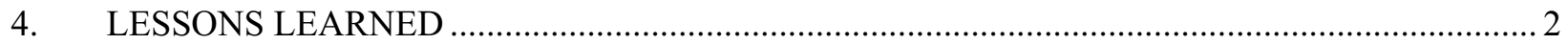

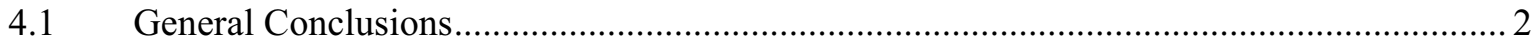

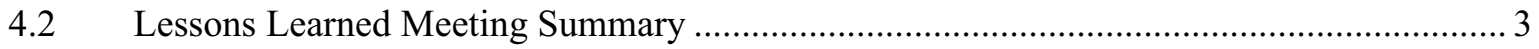

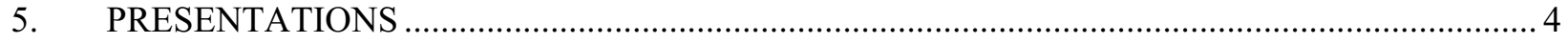

5.1 Texas A\&M University Nuclear Science Center TRIGA Reactor Performance

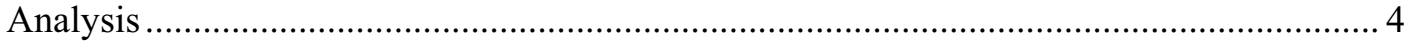

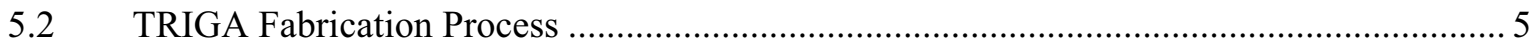

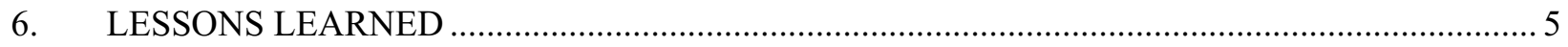

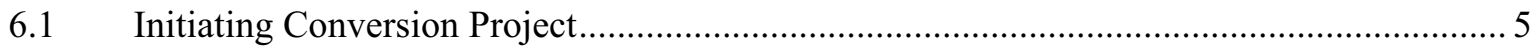

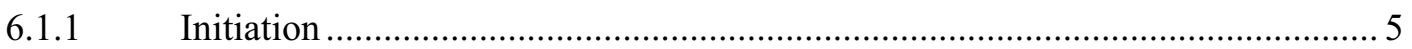

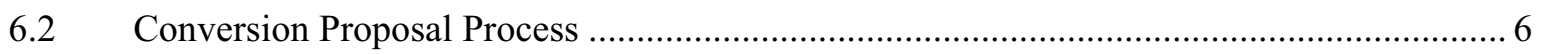

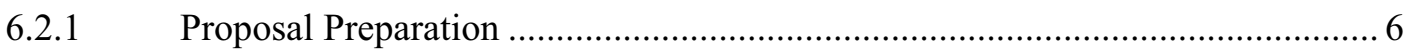

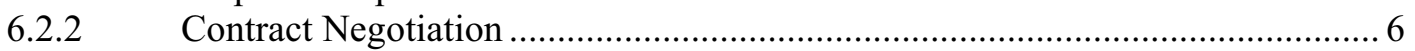

6.3 Fuel and Hardware Development and Procurement...................................................... 7

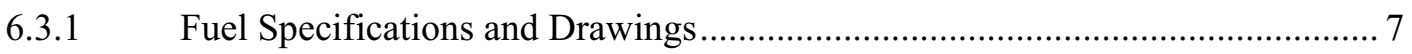

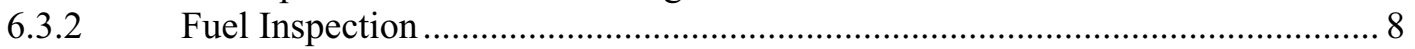

6.3.3 Preparation of Facility for Fuel Receipt .................................................... 8

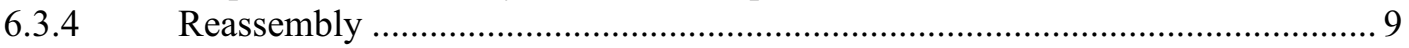

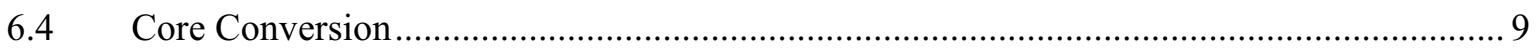

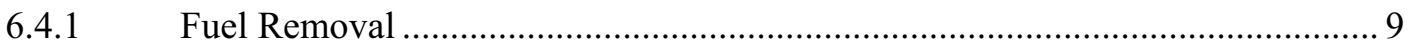

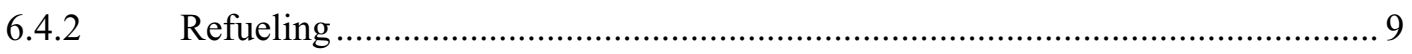




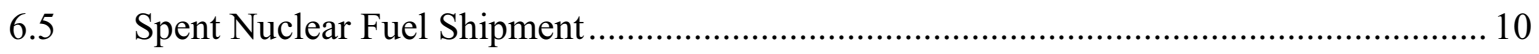

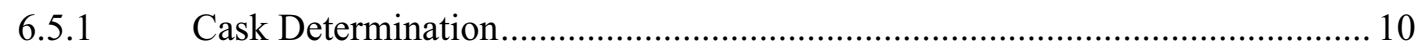

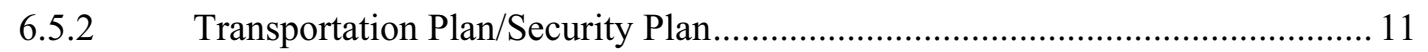

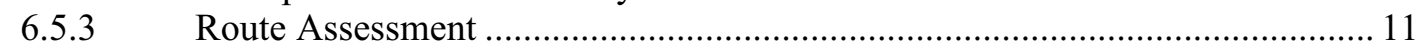

6.5.4 Certification of University Quality Assurance Programs................................ 12

6.5.5 Facility Preparations for Spent Nuclear Fuel Activities..................................... 12

6.5.6 Required Shipping Data Preparation............................................................... 12

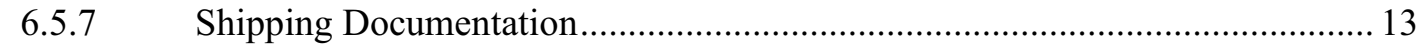

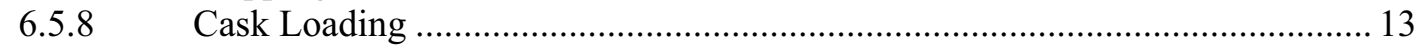

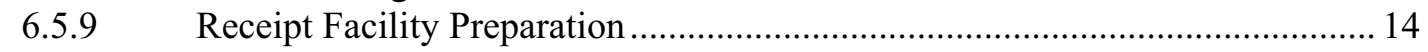

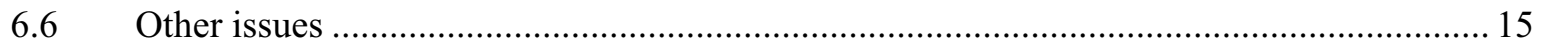

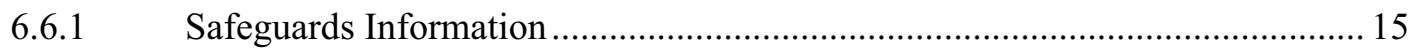

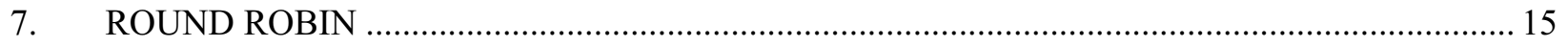




\section{ACRONYMS}

ANL Argonne National Laboratory

DOE U.S. Department of Energy

GA General Atomics

HEU highly enriched uranium

INL Idaho National Laboratory

LEU low-enriched uranium

NNSA National Nuclear Security Administration

NRC Nuclear Regulatory Commission

NSC Nuclear Science Center

SNF spent nuclear fuel

TAMU Texas A\&M University 


\section{University Reactor Conversion Lessons Learned Workshop for Texas A\&M Nuclear Science Center}

\section{INTRODUCTION}

The Department of Energy's (DOE) Idaho National Laboratory (INL), under its programmatic responsibility for managing the University Research Reactor Conversions, has completed the conversion of the reactor at the Texas A\&M University Nuclear Science Center (TAMU NSC). This project was successfully completed through an integrated and collaborative effort involving INL, Argonne National Laboratory (ANL), DOE (headquarters and the field office), the Nuclear Regulatory Commission (NRC), the universities, and the contractors involved in analyses, fuel design and fabrication, and spent nuclear fuel (SNF) shipping and disposition. With this work completed and in anticipation of other impending conversion projects, INL convened and engaged the project participants in a structured discussion to capture the lessons learned. The objectives of this meeting were to capture the observations, insights, issues, concerns, and ideas of those involved in the reactor conversions so that future efforts can be conducted with greater effectiveness, efficiency, and with fewer challenges.

\section{BACKGROUND}

As part of the Bush administration's effort to reduce the amount of weapons-grade nuclear material worldwide, the National Nuclear Security Administration (NNSA) has established a program to convert research reactors from using highly enriched uranium (HEU) to low-enriched uranium (LEU) fuel.

The research reactor conversion effort is a critical step under the Global Threat Reduction Initiative's Reduced Enrichment for Research and Test Reactors program. As part of this program, NNSA is minimizing the use of HEU in civilian nuclear programs by converting research reactors and radioisotope production processes to the use of LEU fuel and targets. The HEU is weapons-grade nuclear material that can be used to make a nuclear weapon or dirty bomb. The research reactors are secure and are used for peaceful purposes; however, by converting these reactors to use LEU, a significant step is made toward ensuring that weapons-usable nuclear material is secure and safeguarded.

Among the list of research reactors targeted for conversion in 2006 were the University of Florida and Texas A\&M University.

Reactor conversions include analyses, LEU fuel fabrication, reactor defuel and refuel activities, HEU packaging and transportation, and reactor startup.

\section{LESSONS LEARNED PROCESS}

The process for capturing the lessons learned from this project involved taking the schedule of the project activities and focusing feedback and discussion on each respective activity. The feedback and lessons learned discussions were held in an open discussion workshop, including all participating team members and their representatives. To promote a more expedient discussion at the workshops and to help the project team focus on the higher priority areas, a survey was developed and sent to project participants before the workshops. The survey invited those involved in the project to score and offer comments with regard to the projects activities in which they were involved. The survey was formatted with a 5-point Likert scale, where 1 was low or "extremely challenging," and 5 was high or "exceptional." The surveys 
were collected and scores were entered and averaged for each activity. The average score for each activity is identified in Section 6 of this document.

Based on survey scores and comments, the workshop agenda was established and timeframes were estimated. Consistent with expectations based on the survey results, the workshop discussions were brief for the unremarkable areas and more extended and detailed in those areas of greatest significance. The detailed lessons learned were captured and the themes and general conclusions were then drawn. The general conclusions and themes tend to apply to all activities (almost as operating principles) and will benefit future project teams and project managers. The more detailed lessons learned align to given activities and apply to the project manager and those involved in the given activity, as that activity is undertaken.

\section{LESSONS LEARNED}

\subsection{General Conclusions}

This project was clearly a success. Nonetheless, there were many detailed lessons learned regarding both technical and project management aspects. The specifics are provided in the following sections; however, some general elements are key to the success of future conversion and spent fuel shipping projects. Future projects will be conducted most effectively, efficiently, and with a minimum of risks, interference, and interruptions if the following are an integral part of the project:

- Project team composition, which includes a project team composed of individuals who are critical thinkers, flexible, and committed to the project results (the following was extracted from the comments submitted: "Having the right people who were willing to buy into the common vision and mission was critical. Everyone had a great personal work ethic. Having a single person who is solely dedicated to the project [allowing that person to stay in contact with all parties involved and to identify and track issues] was instrumental in the success of the project.").

- Communication, including inclusive communications and exchange that provides for effective sharing of needs, expectations, roles, responsibilities, data, assumptions, schedules, and facility and equipment constraints.

- Use of expertise, including confidence in and effective utilization of the varied expertise and experience of the team members.

- $\quad$ Proactivity and individual levels of initiative.

- Early initiation includes the earliest possible initiation of planning and activities at every step in the project process, thereby minimizing the likelihood of time-critical situations.

- Verification and re-verification of data, analyses, specs, assumptions, performance expectations, and equipment fit and function throughout the project.

- Clear and common understanding, including clear expectations of roles, responsibilities, technical variables, and technical results.

- Knowledgeable and informed stakeholders who can advocate for the project, remove barriers, and support decisions and adjustments needed to ensure project success (e.g., public, political, and administrative). 
- Compile reactor data includes assembly or compilation of the historical documents that reveal what is known and unknown about the reactor.

- Value-added government oversight, in which the public interests are served, objectivity is retained, but NRC's experience and expertise is available to the project.

The above list comprised the general themes of the lessons learned meeting. The detailed lessons learned were discussed in the order of project activities, from initiation to closeout, and are provided in the following sections.

\subsection{Lessons Learned Meeting Summary}

The Lessons Learned Workshop for the Texas A\&M University Nuclear Science Center convened on February 21, 2007, at the General Atomics (GA) facilities in San Diego, California. The following were attendees at the workshop:

$\begin{array}{ll}\text { Dana Meyer, INL } & \text { John Bolin, GA } \\ \text { Eric Woolstenhulme, INL } & \text { Jason Yi, GA } \\ \text { Doug Morrell, INL } & \text { Ken Mushinski, GA } \\ \text { Dale Luke, INL } & \text { Pierre Colomb, CERCA } \\ \text { Jim Wade, DOE-ID } & \text { Helios Nadal, CERCA } \\ \text { Parrish Staples, DOE-NNSA } & \text { Jim Matos, ANL } \\ \text { Scott Declue, DOE-SRS } & \text { Jim Remlinger, TAMU } \\ \text { Alexander Adams, NRC } & \text { W Dan Reece, TAMU } \\ \text { Bill Schuser, NRC } & \text { Jamie Adam, NAC } \\ \text { Anthony Veca, GA } & \end{array}$

The following was the agenda for the workshop:

8:00 Welcome and introductory remarks, establish ground rules, and review agenda

8:30 Presentations

- $\quad$ TAMU NSC TRIGA Reactor Performance Analysis-TAMU NSC

- $\quad$ TRIGA Fabrication Process_-TRIGA International 
9:00 Discuss and collect lessons learned by each major activity area

- $\quad$ Initiating Conversion Project

- Conversion Proposal Process

10:15 Break

10:30 Discuss and collect lessons learned by each major activity area (continued)

- $\quad$ Fuel and Hardware Development and Procurement

12:00 Lunch

1:00 Discuss and collect lessons learned by each major activity area (continued)

- Core Conversion

- SNF Shipment

2:20 Break

2:35 Discuss and collect lessons learned by each major activity area (continued)

- $\quad$ Other areas needing to be addressed

3:35 Next steps and assignments

4:10 Closing remarks

4:30 Adjourn

\section{PRESENTATIONS}

\subsection{Texas A\&M University Nuclear Science Center TRIGA Reactor Performance Analysis}

Dr. Dan Reece summarized the TAMU NSC reactor conversion in his presentation. Dr. Reece concluded that many things went very well, but there were a few problems. Dr. Reece also gave his perspective on the lessons to be learned from the conversion work. Highlights from Dr. Reece's presentation include the following:

- $\quad$ The difference between calculated values for fuel element temperatures and the actual measured values of the new core

- $\quad$ The apparent conflict between calculated values for neutron fluxes and the fluxes derived from foil experiments in the new core

- The importance of interactions and relationships with the various regulators and conversion team members 
- The importance of planning and coordination for the project

- $\quad$ The difficulty of locating specific details about the old core.

\subsection{TRIGA Fabrication Process}

This joint presentation covered the ongoing research concerning the difference between the calculated values for fuel element temperatures and the actual measured values of the new NSC core. Additionally, it was shown that the NSC fuel elements fabricated by CERCA were produced in compliance with GA technical specifications and CERCA's quality assurance requirements. The fuel elements were delivered on time and in accordance with the initial manufacturing schedule.

The process for assembling TRIGA elements was discussed. The point was made that inserting the meats into the cladding is a difficult process because of tight cladding tolerances. About $60 \%$ of the fuel elements must have the fuel meats pressed into the cladding. Only meats and cladding with a large gap actually just slide in.

For the instrumented fuel elements, the meat diameters were within tolerance, but at the small end of the ID tolerance. The cladding ID was larger than is allowed per the drawings, but it was determined that it was within the safety analysis report specifications and was cleared for use. This configuration translated to a larger than nominal gap between the meat and the cladding. This gap reduces heat transfer from the meat to the cladding and causes the fuel temperature to be higher than optimal. As the meat swells from operating the reactor, the gap will decrease and the temperature will be lower.

The ostensible decrease in neutron flux was also discussed. The matter needs further investigation and foil testing and the results will be documented in a report by GA.

\section{LESSONS LEARNED}

The detailed lessons learned were discussed in order of project activities, from initiation to closeout, and are provided in the following sections.

\subsection{Initiating Conversion Project}

\subsubsection{Initiation}

The average survey score was 3.88 .

\begin{tabular}{|l|l|}
\hline \multicolumn{1}{|c|}{ Issues } & \multicolumn{1}{|c|}{ Recommendations } \\
\hline $\begin{array}{l}\text { Some reactor specifications were difficult to } \\
\text { ascertain and came late in the project. Some of } \\
\text { this was because the contract with GA was } \\
\text { finalized later than optimum. }\end{array}$ & $\begin{array}{l}\text { Early involvement of GA is imperative to better } \\
\text { understand the core and project implications } \\
\text { (e.g., fuel and hardware). Also, GA should be } \\
\text { invited to the reactor early in the process, with } \\
\text { procurement and analysis aspects being a key } \\
\text { focus. }\end{array}$ \\
\hline
\end{tabular}




\begin{tabular}{|l|l|}
\hline \multicolumn{1}{|c|}{ Issues } & \multicolumn{1}{|c|}{ Recommendations } \\
\hline $\begin{array}{l}\text { The initial license amendment followed an old } \\
\text { example rather than following the NRC guidance } \\
\text { document, NUREG-1537. This resulted in some } \\
\text { unnecessary rewriting. }\end{array}$ & $\begin{array}{l}\text { Follow NUREG-1537 rather than relying on } \\
\text { previous amendments. Reviewing past requests } \\
\text { for additional information from NRC may also be } \\
\text { of benefit. }\end{array}$ \\
\hline
\end{tabular}

\subsection{Conversion Proposal Process}

\subsubsection{Proposal Preparation}

The average survey score was 2.83 .

\begin{tabular}{|l|l|}
\hline \multicolumn{1}{|c|}{ Issues } & \multicolumn{1}{|c|}{ Recommendations } \\
\hline $\begin{array}{l}\text { An interactive request for additional information } \\
\text { resolution meeting with all parties involved was a } \\
\text { key activity. This was much more effective than } \\
\text { trading phone calls and emails. The face-to-face } \\
\text { and open, direct communication was key. This } \\
\text { reduced the required time to complete the process } \\
\text { by a factor of } 10 .\end{array}$ & $\begin{array}{l}\text { Teamwork is critical to success and efficiency of } \\
\text { the proposal process. }\end{array}$ \\
\hline
\end{tabular}

\subsubsection{Contract Negotiation}

The average survey score was 3.0.

\begin{tabular}{|c|c|}
\hline Issues & Recommendations \\
\hline $\begin{array}{l}\text { The procurement process on both sides } \\
\text { (i.e., government and university) is problematic. } \\
\text { Lack of a mutual understanding in the } \\
\text { procurement process lends to bogging down the } \\
\text { process. }\end{array}$ & $\begin{array}{l}\text { Promote communications and negotiations } \\
\text { between the principle project parties before going } \\
\text { to the procurement agents. Once the terms are } \\
\text { understood, then the procurement people can be } \\
\text { brought in to complete the process. } \\
\text { Involve both procurement agents early on to } \\
\text { ensure that time is not lost negotiating differences } \\
\text { between processes and waiting for additional } \\
\text { information later. } \\
\text { Early initiation involvement and coordination of } \\
\text { contracts/procurement staff are crucial. }\end{array}$ \\
\hline
\end{tabular}




\subsection{Fuel and Hardware Development and Procurement}

\subsubsection{Fuel Specifications and Drawings}

The average survey score was 2.20 .

\begin{tabular}{|c|c|}
\hline Issues & Recommendations \\
\hline $\begin{array}{l}\text { Specifics about the fuel and hardware } \\
\text { procurement were confusing because of the varied } \\
\text { opinions and individual spreadsheets. }\end{array}$ & $\begin{array}{l}\text { It would be helpful to get everyone together at the } \\
\text { onset and create a format for presenting the fuel } \\
\text { and hardware information that everyone agrees to } \\
\text { and understands. Drawings and other historical } \\
\text { documents could be presented at the initial } \\
\text { meeting. The various parties could discuss the } \\
\text { data to ensure mutual agreement on what needs to } \\
\text { be ordered. One person could be charged with } \\
\text { keeping the fuel and hardware spreadsheet } \\
\text { updated and issued to the interested parties. }\end{array}$ \\
\hline $\begin{array}{l}\text { Specifics about the fuel and hardware } \\
\text { procurement were confusing because no cluster } \\
\text { assembly information was provided to the } \\
\text { university. }\end{array}$ & $\begin{array}{l}\text { See above recommendation. Also, GA could } \\
\text { provide information about which upper and lower } \\
\text { adapters (and other hardware) are required for the } \\
\text { various cluster types. }\end{array}$ \\
\hline $\begin{array}{l}\text { The gram loading for the fuel elements was on the } \\
\text { low end of the required range. }\end{array}$ & $\begin{array}{l}\text { The project should advise TRIGA International to } \\
\text { load the elements on the heavy side to maximize } \\
\text { the amount of fuel in the core. This maximizes the } \\
\text { per element value when considering the dollars } \\
\text { spent on fabrication, shipping, usage, and disposal } \\
\text { of a fuel rod. }\end{array}$ \\
\hline $\begin{array}{l}\text { Having the fabrication data for the new fuel } \\
\text { earlier in the process would be helpful. }\end{array}$ & $\begin{array}{l}\text { This effort must be worked with the university to } \\
\text { ensure that all needed information is provided in } \\
\text { the data packages. } \\
\text { As a minimum, the data packages should be } \\
\text { included with the fuel shipment. } \\
\text { Caution must be taken to properly handle } \\
\text { proprietary information. }\end{array}$ \\
\hline
\end{tabular}




\subsubsection{Fuel Inspection}

The average survey score was 4.00 .

\begin{tabular}{|l|l|}
\hline \multicolumn{1}{|c|}{ Issues } & \multicolumn{1}{|c|}{ Recommendations } \\
\hline $\begin{array}{l}\text { The fuel receipt inspection worked well at the } \\
\text { reactor and at CERCA. }\end{array}$ & $\begin{array}{l}\text { The right people were involved in the inspection } \\
\text { (i.e., vendor, quality assurance personnel, and } \\
\text { receivers). A coordination meeting was held } \\
\text { before the inspection so that everyone involved } \\
\text { was well advised and clearly understood their } \\
\text { rolls. A source inspection was conducted at the } \\
\text { manufacturer site in France before shipment so } \\
\text { that the receipt inspection at the university was } \\
\text { less complex and time intensive. }\end{array}$ \\
\hline $\begin{array}{l}\text { After inspection, it was unclear who took } \\
\text { ownership of the fuel. }\end{array}$ & $\begin{array}{l}\text { There needs to be a clear transfer of responsibility } \\
\text { so that it is understood who owns the fuel at any } \\
\text { given time. A signature process could be devised } \\
\text { that formally documents and completes the } \\
\text { ownership transfer. }\end{array}$ \\
\hline
\end{tabular}

\subsubsection{Preparation of Facility for Fuel Receipt}

The average survey score was 3.60.

\begin{tabular}{|l|l|}
\hline \multicolumn{1}{|c|}{ Issues } & \multicolumn{1}{|c|}{ Recommendations } \\
\hline $\begin{array}{l}\text { The truck/trailers arrived at NSC with the } \\
\text { containers positioned toward the front of the } \\
\text { trailers and with some of the containers turned } \\
\text { sideways; this precluded access with a pallet jack } \\
\text { or forklift. }\end{array}$ & $\begin{array}{l}\text { Information about the shipping trucks and loading } \\
\text { configuration is important to expedite the receipt } \\
\text { of the fuel at the reactor. Ii would be best if the } \\
\text { trailers had a side-loading capability to make it } \\
\text { easier to unload the shipments with a forklift. The } \\
\text { INL should facilitate communications between the } \\
\text { shipper and reactor. The INL should consider } \\
\text { writing truck specifications into the contract with } \\
\text { the shipping company. }\end{array}$ \\
\hline
\end{tabular}




\subsubsection{Reassembly}

The average survey score was 3.33.

\begin{tabular}{|l|l|}
\hline \multicolumn{1}{|c|}{ Issues } & \multicolumn{1}{|c|}{ Recommendations } \\
\hline $\begin{array}{l}\text { It may take specific training to open and } \\
\text { reassemble the shipping containers for return } \\
\text { shipment. }\end{array}$ & $\begin{array}{l}\text { Dave Capp at the INL was this person for the } \\
\text { TAMU NSC project. He did a great job. The INL } \\
\text { needs to secure a similar individual on all future } \\
\text { projects. }\end{array}$ \\
\hline
\end{tabular}

\subsection{Core Conversion}

\subsubsection{Fuel Removal}

The average survey score was 3.33.

\begin{tabular}{|l|l|}
\hline \multicolumn{1}{|c|}{ Issues } & \multicolumn{1}{|c|}{ Recommendations } \\
\hline Fuel removal went well at NSC. & $\begin{array}{l}\text { Video taping of the processes will serve as a great } \\
\text { resource for those who must perform the tasks } \\
\text { later. }\end{array}$ \\
$\begin{array}{l}\text { It may be beneficial to have the core parameters } \\
\text { measured and documented before the reactor is } \\
\text { shutdown for refueling (i.e., fuel temperatures, } \\
\text { neutron flux, and control rod positions). The } \\
\text { measurements may be useful in analysis following } \\
\text { restart. }\end{array}$ \\
\hline
\end{tabular}

\subsubsection{Refueling}

The average survey score was 3.50.

\begin{tabular}{|l|l|}
\hline \multicolumn{1}{|c|}{ Issues } & \multicolumn{1}{c|}{ Recommendations } \\
\hline $\begin{array}{l}\text { Personnel turnover at the universities can } \\
\text { sometimes cause a loss of drawings, } \\
\text { specifications, and other documents. This can } \\
\text { make converting the reactor and SNF shipments a } \\
\text { significant challenge. }\end{array}$ & $\begin{array}{l}\text { Early notification of the documentation needs by } \\
\text { the INL should be made to the university. This } \\
\text { will allow more time for locating the information. }\end{array}$ \\
\hline
\end{tabular}




\begin{tabular}{|l|l|}
\hline \multicolumn{1}{|c|}{ Issues } & \multicolumn{1}{|c|}{ Recommendations } \\
\hline $\begin{array}{l}\text { Hardware for NSC had to be re-machined because } \\
\text { of lack of information. GA was quick to respond } \\
\text { to all issues identified; therefore, the issues were } \\
\text { resolved quickly. }\end{array}$ & $\begin{array}{l}\text { An early start can also allow time for reactor } \\
\text { personnel to physically verify reactor components } \\
\text { before procurement of the parts. } \\
\text { Because of this issue, we must pay greater } \\
\text { attention to the details of the reactors. }\end{array}$ \\
\hline $\begin{array}{l}\text { The instrumented fuel elements read higher than } \\
\text { expected from the earlier analysis. }\end{array}$ & $\begin{array}{l}\text { Instrumented fuel elements cladding and fuel meat } \\
\text { gaps must be tighter to ensure that the actual } \\
\text { readings are more representative of the core } \\
\text { analysis. }\end{array}$ \\
\hline $\begin{array}{l}\text { Thermocouple leads on the instrumented fuel } \\
\text { elements were too long for the NSC configuration. } \\
\text { The NSC cut the leads, but then required a half } \\
\text { day to re-work the lead wires. }\end{array}$ & $\begin{array}{l}\text { The correct length should be identified before } \\
\text { fabrication at CERCA. Cutting the thermocouple } \\
\text { leads is standard practice, but had it been } \\
\text { considered ahead of time, the materials and } \\
\text { capabilities could have been in place onsite to } \\
\text { significantly reduce the time and effort required. }\end{array}$ \\
\hline
\end{tabular}

\subsection{Spent Nuclear Fuel Shipment}

\subsubsection{Cask Determination}

The average survey score was 3.67.

\begin{tabular}{|l|l|}
\hline \multicolumn{1}{|c|}{ Issues } & \multicolumn{1}{|c|}{ Recommendations } \\
\hline $\begin{array}{l}\text { The SNF shipment activities are very difficult for } \\
\text { universities that do not normally ship SNF. }\end{array}$ & $\begin{array}{l}\text { Updated guidance from NRC regarding SNF } \\
\text { shipping would be helpful. } \\
\text { The INL should consider contracting with other } \\
\text { companies or experienced shippers to help the } \\
\text { licensees. }\end{array}$ \\
$\begin{array}{l}\text { The DOE could consider taking ownership of the } \\
\text { shipping rather than NRC. }\end{array}$ \\
\hline $\begin{array}{l}\text { Not everyone with a need to know had copies of } \\
\text { the SNF shipping orders, specifically, some } \\
\text { information needed to be included in shipping } \\
\text { documents prepared by others. This was caused, } \\
\text { in part, by a Safeguards Information "blackout" } \\
\text { for information from NRC. }\end{array}$ & $\begin{array}{l}\text { Safeguarded Information issues have been } \\
\text { resolved at NRC. This situation should not occur } \\
\text { in the future. }\end{array}$ \\
\hline
\end{tabular}




\begin{tabular}{|l|l|}
\hline \multicolumn{1}{|c|}{ Issues } & \multicolumn{1}{|c|}{ Recommendations } \\
\hline $\begin{array}{l}\text { The cask was identified much later than } \\
\text { appropriate by INL. The tardiness of the contract } \\
\text { with the cask vendor caused delays in the facility } \\
\text { preparations. This caused unnecessary stress and } \\
\text { work for NSC. }\end{array}$ & $\begin{array}{l}\text { The INL needs to make cask arrangements as } \\
\text { soon as possible. }\end{array}$ \\
The cask vendors need to make detailed site \\
assessments early in the project. \\
$\begin{array}{l}\text { Drawings and procedures need to be supplied to } \\
\text { the reactor as soon as possible. } \\
\text { The project should make early visits to the } \\
\text { university and discuss the tasks associated with } \\
\text { SNF shipping. }\end{array}$ \\
\hline
\end{tabular}

\subsubsection{Transportation Plan/Security Plan}

The average survey score was 3.0.

\begin{tabular}{|l|l|}
\hline \multicolumn{1}{|c|}{ Issues } & \multicolumn{1}{|c|}{ Recommendations } \\
\hline $\begin{array}{l}\text { Transport and security plans can be } \\
\text { time-consuming and labor intensive. }\end{array}$ & $\begin{array}{l}\text { The project should get the most effective and } \\
\text { reliable sources to carry out the functions of } \\
\text { developing the plans. }\end{array}$ \\
\hline $\begin{array}{l}\text { Guidance form NRC regarding HEU shipments } \\
\text { was not as clear or up-to-date as it could have } \\
\text { been. }\end{array}$ & $\begin{array}{l}\text { The current guidance should be updated. The } \\
\text { NRC suggests we work with one of the current } \\
\text { licensees to get better understanding of the current } \\
\text { regulations. }\end{array}$ \\
\hline
\end{tabular}

\subsubsection{Route Assessment}

The average survey score was 3.2.

\begin{tabular}{|l|l|}
\hline \multicolumn{1}{|c|}{ Issues } & \multicolumn{1}{|c|}{ Recommendations } \\
\hline $\begin{array}{l}\text { Communication about the route assessment } \\
\text { documents was sometimes inefficient. }\end{array}$ & $\begin{array}{l}\text { It was suggested to involve other subject matter } \\
\text { experts during the route assessment. } \\
\text { Communication lines between all parties } \\
\text { (i.e., shipper, INL, cask vendor, and other } \\
\text { facilitating companies) need to be open. }\end{array}$ \\
\hline
\end{tabular}




\subsubsection{Certification of University Quality Assurance Programs}

The average survey score was 3.0.

\begin{tabular}{|l|l|}
\hline \multicolumn{1}{|c|}{ Issues } & \multicolumn{1}{|c|}{ Recommendations } \\
\hline Certifying as an SNF shipper can be extensive. & $\begin{array}{l}\text { Begin activities early and the program should } \\
\text { provide assistance to the facility, as needed. }\end{array}$ \\
\hline
\end{tabular}

\subsubsection{Facility Preparations for Spent Nuclear Fuel Activities}

The average survey score was 3.60.

\begin{tabular}{|l|l|}
\hline \multicolumn{1}{|c|}{ Issues } & \multicolumn{1}{|c|}{ Recommendations } \\
\hline $\begin{array}{l}\text { The SNF shipping preparations are wide-ranging } \\
\text { and often difficult. }\end{array}$ & $\begin{array}{l}\text { Need to ensure early, comprehensive planning } \\
\text { with attention to detail. } \\
\text { Start the process to procure support equipment } \\
\text { (e.g., cranes) early. This worked well for us. }\end{array}$ \\
\hline
\end{tabular}

\subsubsection{Required Shipping Data Preparation}

The average survey score was 2.5 .

\begin{tabular}{|l|l|}
\hline \multicolumn{1}{|c|}{ Issues } & \multicolumn{1}{|c|}{ Recommendations } \\
\hline $\begin{array}{l}\text { Required shipping data preparations can be } \\
\text { laborious and resource intensive. }\end{array}$ & $\begin{array}{l}\text { Use of the parametric study on TRIGA fuel } \\
\text { burnups for completing the required shipping data } \\
\text { radioisotope and decay heat tables would be very } \\
\text { effective. }\end{array}$ \\
$\begin{array}{l}\text { The university may need to check and validate the } \\
\text { applicability of the standard decay heat data. }\end{array}$ \\
\hline
\end{tabular}




\subsubsection{Shipping Documentation}

The average survey score was 3.0.

\begin{tabular}{|l|l|}
\hline \multicolumn{1}{|c|}{ Issues } & \multicolumn{1}{|c|}{ Recommendations } \\
\hline $\begin{array}{l}\text { Shipping documentation, such as SNF } \\
\text { Transportation Plans and the Bill of Lading, were } \\
\text { very involved for an unfamiliar shipper. }\end{array}$ & $\begin{array}{l}\text { The INL's help was invaluable. The university } \\
\text { always felt that they had an ally and } \\
\text { knowledgeable resource to facilitate the process. } \\
\text { The project university also had confidence in the } \\
\text { experts and could trust their advice and } \\
\text { experience during document development. }\end{array}$ \\
\hline
\end{tabular}

\subsubsection{Cask Loading}

The average survey score was 3.67.

\begin{tabular}{|l|l|}
\hline \multicolumn{1}{|c|}{ Issues } & \multicolumn{1}{|c|}{ Recommendations } \\
\hline $\begin{array}{l}\text { The SNF roles and responsibilities were well } \\
\text { defined going into the SNF shipping activities. }\end{array}$ & $\begin{array}{l}\text { The NSC had been informed early in the project } \\
\text { that they were in charge and responsible for the } \\
\text { activities. All other entities also understood this at } \\
\text { the outset of the project. This hierarchy resulted in } \\
\text { effective working relationships between the } \\
\text { project entities. } \\
\text { We need to maintain this level of rigor and } \\
\text { discipline for future conversion projects. }\end{array}$ \\
\hline
\end{tabular}




\begin{tabular}{|l|l|}
\hline \multicolumn{1}{|c|}{ Issues } & \multicolumn{1}{|c|}{ Recommendations } \\
\hline $\begin{array}{l}\text { The cask sat loaded at NSC over the weekend. } \\
\text { This was an unfavorable situation for the shipper. }\end{array}$ & $\begin{array}{l}\text { Many notifications and logistics have to be } \\
\text { worked out for the moment the shipment leaves } \\
\text { the facility. Changes to planned shipping dates are } \\
\text { difficult if not impossible to effect. The SNF } \\
\text { loading was to begin on Monday. It was estimated } \\
\text { that loading would take about } 5 \text { days to complete, } \\
\text { thereby finishing on Friday. Weekends are not the } \\
\text { preferred times to start shipments; therefore, the } \\
\text { INL shipping coordinator felt that it was best to } \\
\text { leave the weekend for schedule contingency in the } \\
\text { case loading took longer than expected. }\end{array}$ \\
$\begin{array}{l}\text { The project needs to fully communicate this } \\
\text { thinking and the firm shipping dates for the } \\
\text { university. }\end{array}$ \\
$\begin{array}{l}\text { In future shipments, the project needs to consider } \\
\text { the trade-off between shipping on a weekend or } \\
\text { leaving the loaded cask at the facility for the } \\
\text { weekend. }\end{array}$ \\
\hline
\end{tabular}

\subsubsection{Receipt Facility Preparation}

The average survey score was 3.33 .

\begin{tabular}{|l|l|}
\hline \multicolumn{1}{|c|}{ Issues } & \multicolumn{1}{|c|}{ Recommendations } \\
\hline $\begin{array}{l}\text { There was some confusion on who was making } \\
\text { arrangements for the return shipments of the } \\
\begin{array}{l}\text { Nuclear Assurance Corporation equipment. Just } \\
\text { days before the shipment, it was found that the } \\
\text { arrangement for a truck had not been made. }\end{array}\end{array}$ & $\begin{array}{l}\text { It needs to be clearly established, well in advance } \\
\text { of the cask loading dates, who is responsible for } \\
\text { planning and executing the tasks for all legs of the } \\
\text { shipments. This includes equipment shipment to } \\
\text { and from the various facilities. }\end{array}$ \\
\hline
\end{tabular}




\subsection{Other issues}

\subsubsection{Safeguards Information}

The average survey score was 3.0.

\begin{tabular}{|l|l|}
\hline \multicolumn{1}{|c|}{ Issues } & \multicolumn{1}{|c|}{ Recommendations } \\
\hline $\begin{array}{l}\text { There was a bit of confusion regarding what } \\
\text { constitutes safeguards information and who can } \\
\text { have access to it. }\end{array}$ & $\begin{array}{l}\text { The various entities involved with the project } \\
\text { need to clearly understand their responsibilities } \\
\text { and limitation under this order. The project should } \\
\text { consider holding an onsite meeting to clarify the } \\
\text { policies with the project team. }\end{array}$ \\
\hline
\end{tabular}

\section{ROUND ROBIN}

In concluding the discussion of the lessons learned, all participants were invited to reiterate, summarize, or offer any other lessons learned. The following list provides their final thoughts:

- Well defined goals and responsibilities are essential to success. All team members must understand their responsibilities. Because of division of responsibilities at INL, it was confusing to NSC who at INL was in charge of some tasks.

- It is important for the project team to understand that if a task can be done early then it should be. Performing tasks just-in-time would have caused the NSC conversion to fail because of unexpected, last-minute tasks and issues. In other words, completing tasks early will allow the project to be flexible enough to address the last minute challenges.

- The NSC project went well in spite of the minor setbacks and challenges. The project will be held to a higher standard of performance next time.

- $\quad$ There will be some weeks/months after the project where parties will need to work together to get some things accomplished and review present issues of conversion.

- The next lessons learned analysis needs to include a specific "what went well" column so that we can capture the things that worked.

\section{CONCLUSION}

This lessons learned process has allowed us to capture gaps, opportunities, and good practices, drawing from the project team's experiences. The process is inclusive and offers an opportunity for every entity that "touched" the project to share from its experience. These lessons will be used to raise the standard of excellence, effectiveness, and efficiency in all future conversion projects. Despite making improvements to successive projects by addressing the lessons we have learned on this project, conducting a lessons learned activity will be vital to each conversion project as technologies, regulations, and other aspects of the environment change and influence success. It is recognized we cannot become complacent, nor adopt a mindset that the process has been "perfected." 